\title{
LACK OF STRATEGIC INTERVENTION IN THE REGULATION OF THE MINIBUS TAXI INDUSTRY IN SOUTH AFRICA
}

\author{
SIYABULELA CHRISTOPHER FOBOSI \\ Nelson R. Mandela School of Law, University of Fort Hare, South Africa
}

\begin{abstract}
The minibus taxi industry was founded by the black community and continues to mainly serve this community. The industry expanded within the framework of the policy of deregulation of the apartheid government. After twenty-six years of democracy, South Africa is still haunted by an informal and unregulated minibus taxi industry. The regulation of the industry has been sought over the years without success. While the state subjects the industry to social control through the entry regulation and route allocation, the state is characterised by a pattern of strategic selectivity (in relation to public transport plans) which shows that institutions (departments) privilege some actors over others. Government practices strategic selectivity by privileging the formalised public transport - buses and trains - over the informal minibus taxi industry. The state has failed to regulate the industry due to a lack of engagement with different actors in the industry. Against this background, this article examines the failed regulation of the industry by the state. It was only through the 2020 National Taxi Lekgotla (a national meeting for the minibus taxi industry) during the October Transport Month that government successfully engaged with the taxi industry, albeit without the participation of the National Taxi Alliance. Using qualitative research methods, the author interviewed research participants to investigate the context of precariousness in South Africa's minibus taxi industry. The author discovered that while the industry is characterised by precarious practices resulting from the employers, these practices are also due to the lack of strategic intervention in the industry as displayed by the state. The author performed a thematic analysis of all the interviews conducted.
\end{abstract}

Keywords: minibus taxi industry, Johannesburg, regulation, unregulation, strategic selectivity, transformation.

\section{INTRODUCTION}

The context of transportation and urban planning in relation to the industry is defined by the existence of registered and unregistered minibus taxis [1]. In 2016, there were approximately 300,876 registered minibus taxis. Unroadworthy and unlicensed minibus taxis were also included in this number, placing the lives of minibus taxi workers and passengers at risk - in the sense of precariousness [1]. The Department of Transport (DoT) reported the following, concerning unroadworthy and unlicensed minibus taxis between December 2015 and December 2016, shown in the following tables.

Table 1 shows that the number of minibuses that are unroadworthy (but licensed) were reported to have increased to 35,718 (2.91\%) in December 2016 from 34,707 in December 2015.

Table 2 shows that the number of unlicensed minibuses also increased to 6,494 (12.98\%) in December 2016, from 5,748 in December 2015.

In addition to this, Table 3 shows that between 2016 and 2017, the number of unlicensed minibuses increased by 781 (13.04\%) in March 2017 from 5,990 minibuses.

This means that, between 2015 and 2017, there was an increase in the number of unlicensed minibuses. Tables 1-3 show that South Africa's minibus taxi industry is characterised by unroadworthy and unlicenced minibus taxis. Unroadworthy minibus taxis 
Table 1: Number of unroadworthy but licensed minibus taxis, 2015-2016.

\begin{tabular}{|l|c|c|c|c|}
\hline \multicolumn{5}{|c|}{ Number of unroadworthy minibus taxis, 2015-2016 } \\
\hline Vehicle type & Dec. 2015 & Dec. 2016 & Change & \% Change \\
\hline Minibuses & 34,707 & 35,718 & 1,011 & 2.91 \\
\hline
\end{tabular}

Table 2: Number of unlicenced minibuses, 2015-2016.

\begin{tabular}{|l|c|c|c|c|}
\hline \multicolumn{5}{|c|}{ Number of unlicensed minibuses, 2015-2016 } \\
\hline Vehicle type & Dec. 2015 & Dec. 2016 & Change & \% Change \\
\hline Minibuses & 5,748 & 6,494 & 746 & 12.98 \\
\hline
\end{tabular}

Table 3: Number of unlicenced minibuses, 2016-2017.

\begin{tabular}{|l|c|c|c|c|}
\hline \multicolumn{5}{|c|}{ Number of unlicensed minibuses, 2016-2017 } \\
\hline Vehicle type & Dec. 2015 & Dec. 2016 & Change & \% Change \\
\hline Minibuses & 5,990 & 6,771 & 781 & 13.04 \\
\hline
\end{tabular}

are those with owners who refuse to apply their vehicles for compulsory annual roadworthy checks or ownership changes. Unlicensed minibuses are those taxi owners who do not renew their vehicle licenses within the timeframe required. This condition implies that the lives of commuters - the majority of the working poor - continue to be at risk by travelling in precarious minibus taxis. Unroadworthy and unlicensed minibus taxis also place taxi drivers in precarious conditions of work, where taxis are not in good condition (unroadworthy) and are at risk of being impounded for being in this condition and not licensed. This in turn places commuters in a condition where they must travel in fear of being involved in accidents. While precarious work was associated only with the retail and hospitality industries in the 1980s, and considered an atypical type of work, it continues to be the norm in the minibus taxi industry. In the context of the registered and unregistered minibus taxis, the State continue to fail successfully regulating the industry. This is due to the refusal of the industry to be regulated and a lack of strategic intervention by the state, as explained in this paper. The industry does not comply with the regulations of institutions such as the Department of Employment and Labour (DoEL). This refusal to be regulated by the state or to allow for state intervention has always characterised the industry since democracy. There are instances where some taxi operators do not have operating licenses, with this indicating an instance of failed strategic intervention by the state.

South Africa's minibus taxi industry exists inside social institutions - the interrelated arrangement of accepted practices and social jobs to fulfil the social need. The industry is arranged around economic institutions (facilitated by the state) which manage economic and property relations. Through social institutions, the state subjects the industry to some form of social control (exemplified through regulations, for example the licensing of taxis). In any case, while the state subjects the industry to social control, the state is portrayed, by an example of strategic selectivity through public transport plans, which shows that institutions (departments) privilege some actors over others. Government practices strategic selectivity by privileging formalised public transport over the unregulated and informal minibus taxi industry. This is an instance of a lack of state strategic intervention which signifies that the industry continues to be neglected to the advantage of formalised public transport modes.

The minibus taxi industry is characterised by complex social processes. The industry has repetitive forms of irregularity existing alongside attempts by the state to regulate it. Social 
processes in the industry occur in the context where taxi owners, taxi drivers and taxi marshals interact with each other. These social processes assisted the author to interpret and understand the context of the lack of state intervention in the industry. The industry keeps on being arranged in what Clarke regards as 'regulated precariousness' [1]. State regulation of the minibus taxi sector have been sought for throughout the years but without success (only challenges). The social processes in the industry help to decide the qualities of taxi operators, taxi drivers and taxi marshals. These processes influence the ways in which taxi industry actors enter into social relationships with each other. Therefore, the processes influence the informal ways defining the nature of the industry. Sociologists have considered five social processes, namely: integration, socialisation, status, power, and adaptation [2]. The social integration process is exemplified by the behaviour of taxi owners, taxi marshals and taxi drivers.

The argument of this paper is that it is important that the minibus taxi industry be incorporated into public transport plans. The aim of this paper is to fill the noticeable gap in the literature on the factors leading to precariousness within the industry - in the Global South (by highlighting that the lack of state intervention is responsible for precariousness in the industry). The majority of literature on the minibus taxi industry concentrates on describing the Taxi Recapitalisation Programme (TRP) and the factors affecting its implementation [3][8], without studying the precariousness of work within the industry. This paper argues that regulation is not just significant for guaranteeing that the industry works, as indicated by the laws of South Africa. Regulation is likewise significant for guaranteeing government subsidies for the sector and furthermore works/contends productively and adequately. As it were, this is an instance of state contribution in the sector. While the state exhibited a lack of strategic intervention in the industry, revealed through the lack of the industry's integration in government plans, including lack of subsidies, it is critical in entry regulation of the industry. While this is so, however, there are cases where taxis are operating illegally. Nevertheless, it is necessary to remember that regulation does not just tackle licensing and allocation of routes. But it additionally addresses regulation of labour conditions in the industry by the Department of Employment and Labour (DoEL), and this is a necessary for affecting unstable states of work inside industry. Nevertheless, the DoEL's regulation has not proved effective because of the industry's failure to comply with labour regulations. This signifies, to some degree, a case of ineffective state interference in relation to labour regulations.

\section{STATE'S STRATEGIC SELECTIVITY}

Jessop states that 'the form of the state is a reflection of the economic base of society and that its interventions are a reflection of the spheres of the economy and/or of the balance of economic class forces' [9]. According to Jessop [9], the state is not an entity but a social relation with different strategic effects. This means that the state is determined by the nature of social relations which it is situated in. Therefore, the introduction of the TRP to transform the minibus taxi industry demonstrated that the state is a social relation. The relation between the state and the industry is 'strategic-relational', to use Jessop's [9] concept, in such a way that it defines the relations between the state and the industry. Nicos Poulantzas laid the foundation for this strategic-relational approach by explaining the nature of social relations. The strategic-relational approach 'analyses social phenomena in terms of social relations through a dialectical analysis of structure and agency in order to examine how institutions privilege some actors and strategies over others, and how strategies structure institutions' [10]. Therefore, through the strategic-relational approach, the state privileges formalised public transport (buses and trains) and strategies over the informal and unregulated minibus 
taxi industry. A key element of strategic selectivity within the South African public transport sector is how government promotes formalised public transport as embodying state selectiveness.

The state privileges formalised public transport strategies over others, because 'institutions are characterised by a pattern of strategic selectivity that reflects and modifies the balance of social forces and, in other word, delineates which interests, strategies, and policies can be enforced in a given context' [10]. In this regard, it appears that government has essentially chosen to attempt to replace the informal taxi industry with various formal modes of transport. The state's intervention in the industry remains unrealised even though the governing party speaks of realising the developmental sate. This article uses the term developmental state to understand state intervention, including regulation and planning. For South Africa to become a true developmental state, government needs to successfully intervene in the minibus taxi industry, amongst other areas. Following the transition from apartheid to democracy, the African National Congress (ANC) government 'adopted the principles of a developmental state with the belief that state economic intervention could enhance and strengthen government or state capacity to deal with the challenges of poverty, unemployment and gross inequalities' [11, p. 58]. Government adopted state economic intervention with a belief that this would strengthen the state's capacity to deal with the multitude of issues inherited from apartheid - for example, racial segregation that the minibus taxi sector encountered [12].

\subsection{Developmental state remains elusive}

Following the transition from apartheid to democracy, the African National Congress (ANC) government 'adopted the principles of a developmental state with the belief that state economic intervention could enhance and strengthen government or state capacity to deal with the challenges of poverty, unemployment and gross inequalities' [11]. Government adopted state economic intervention with a belief that this would strengthen the state's capacity to deal with the multitude of issues inherited from apartheid - for example, racial segregation that the minibus taxi sector encountered [12]. Spatial and racial segregation during apartheid resulted in a removal of black people from the centre of many cities. During this period, transport was used to control access to urban areas. The government of the time invested in road infrastructure for private vehicles, neglecting public transport. Apartheid resulted in a legacy of social and spatial segregation, with people separated from their places of work and social services. Black people were forced to live in the townships and were, therefore, separated from their places of work. Often, the only mode of transport they had were minibus taxis. It is important to note that public transportation is a critical part of any country's development. Therefore, the development of the minibus taxi industry in South Africa depends on the state's capacity to implement a developmentalist agenda. According to Freund, 'a developmental state will involve a deeply embedded partnership between the state and at least parts of capital in pursuit of common projects leading to economic growth' [13]. The minibus taxi industry is important because it enables many economic and societal activities. As such, partnership between the state and the minibus taxi industry will ensure that it not only contributes to economic growth, but also has good working conditions and decent wages for taxi drivers and taxi marshals.

Mathebula states that a developmental state is one 'that totally endeavour to deploy its administrative and political resources to the task of economic development' [14]. According to Edigheji, 'a developmental state is a phenomenon that existed in a particular context of East Asia between the 1950s and 1980s to explain the rapid economic growth of the countries 
in East Asia' [15]. 'In Korea, the developmental state emerged in earnest from the early 1960 s, and combined with authoritarian politics in the 1970s, labelling the 1970s Korea as typical of the authoritarian developmental state' [16]. While South Korea's developmental state succeeded in achieving its main goals through economic growth and industrialisation, its social policies were underdeveloped. Since the end of the Second World War, the East Asian countries experienced economic development due to a unique "Asian model," which maintained international market forces and economic growth through state intervention. The socio-economic context from Asia drew the world to the discussions of a developmental state as an opportunity to address developmental challenges in developing countries [12]. However, Mathebula argues that in the Asian developmental states, the state has a dictatorship role in forcing the market to drive the developmental agenda through predetermined goals and pace while the South African only thrives through regulatory role to the market' [14]. The context of the developmental state is to understand the role of the state in ensuring the development of the minibus taxi industry.

The term developmental state was first conceptualised by Chalmers Johnson in the 1980s, where he defined a developmental state as a state with a focus on economic development and taking the necessary policy measures to achieve such development. Freund argues that 'South Africa in the twentieth century can actually be understood as a nascent developmental state, with economic development acting as a key motivating factor' [13]. The nascent developmental state can be observed in the case of failed state intervention within the minibus taxi industry. The state has failed to regulate the industry due to a lack of engagement with different actors in the sector. It was only through the 2020 National Taxi Lekgotla (during the October Transport Month) that government successfully engaged with the taxi industry, albeit without the participation of the National Taxi Alliance. In an effort to formalise the minibus taxi industry, the Department of Transport (DoT) held a National Taxi Lekgotla, during the 2020 October Transport Month, to discuss ways in which the state of the industry could be improved. The Lekgotla (held between 29 October and 31 October 2020) was longawaited, as violence and strife triggered by turf wars and leadership struggles continue unabated and unity in the industry remains a challenge.

According to Mkandawire, 'during much of the 1980s and 1990s, a literature emerged suggesting that "developmental states" were impossible in Africa' [17]. Mkandawire states that the literature on developmental states has two components. The first one is the ideological component, and the second structural. In terms of the first component, the developmental state is defined in terms of ideology. States with a developmentalist ideology are focused on promoting sustained economic development and economic growth. In terms of the ideological component, the state assumes a character that is developmentalist, with a mission of ensuring economic development associated with high rates of accumulation and industrialisation. Based on the second component, a structural definition, Mkandawire argues that 'the developmental state emphasises capacity to implement economic policies wisely and effectively' [17]. The capacity of the state is defined by different factors, including technical, institutional, administration and political [13]. However, the ANC government does not seem to have the capacity to implement policies to transform the minibus taxi industry, given the TRP's minimal impact on the industry's precarious conditions of work. Writing on the South African developmental state, Marais writes that 'government wheeled out the developmental state project in the early 2000s, as criticism of its structural adjustment policies grew shrill' [18]. While the South African government has adopted measures such as the transformation of the minibus taxi industry in order to achieve the economic development of this industry, it has failed to achieve this due to a lack of intervention. 
The definition of the developmental state 'is always deductively derived from the economic results' [17]. Therefore, a state is developmental if the economy is developing - in other words, if it is growing. Marais argues that a developmental state has "autonomy" to promote social development through economic growth. The ANC tends to associate the developmental state 'with the achievements of the newly industrialised countries of Asia' [18]. Evans argues that the state is involved in economic transformation and because of this, it is implicated in the process of capital accumulation [19]. As states become increasingly involved in economic transformation, they look at the international system not only as a system of sovereign political entities but also as a division of labour. According to Evans, 'in the contemporary world, withdrawal and involvement are not the alternatives. State involvement is a given' [19].

While Edigheji finds that there is enough political will for a developmental state [15], I think the state seems to downplay contexts where this is not the case, such as the lack of political will to fix the minibus taxi industry. Institutions will play an important role in determining the developmental state's capacity to implement the TRP in the context of the industry. Since the developmental state involves an embedded relationship between the state and parts of capital, one would expect the state to give direction to the minibus taxi industry in significant ways. Starting in the 1960s, in South Africa, 'the state re-oriented itself towards entrenching the apartheid racial divisions into a national partition and became obsessed with security issues' [13]. As a result, economic and developmental goals were not important unless attached to racial divisions and security issues. The developmental state in South Africa enjoyed much success in the mining/financial sector focused on gold. This dependence of the economy on the mining sector was very strong, by 1940 'with Anglo-American as the locally based premier firm' [13]. The South African economy and its development have been relatively weak globally in terms of the manufacturing sector. Unlike Asia, South Africa faced isolation from other parts of the world, especially the major trading economies [14]. 'From 1975 South Africa increasingly depended not on the manufacturing sector but rather on the growing sale of other minerals such as manganese, platinum, iron ore and coal' [13]. Investment in the minibus taxi industry was largely neglected, irrespective of its role in economic growth. More focus was placed on developing the extensive rail network. Also, government has over the years until recently, appeared to have chosen to attempt replacing the minibus taxi industry with formal public transport modes.

There is also a lack of political will to develop the South African public transport system. Certainly, without the existence of a competent and capable public bureaucracy, expanding public transport to include the minibus taxi industry will take time to materialise. Therefore, for South Africa to be able to successfully implement a developmental state in the $21 \mathrm{st}$ century, it needs new kinds of capabilities [11]. While this is important, it is equally vital that the state shows political will towards the transformation of the minibus taxi industry while taking cognisance that there continues to be some resistance from the industry to participate in this regulation or transformation through the DoL and enforcement of labour regulations. There are cases of a lack of political will to address problems which the industry faces, indicating a vision of a sustainable state deferred in the industry's sense.

Tshishonga and de Vries argue that 'taking the developmental state model seriously and taking it to its utmost, would imply also that the South African state focuses on protecting and stimulating the growth of its main domestic industry' [11]. This does not mean facilitating the maximisation of profit within the minibus taxi industry, for example, but maximising its market share within the public transport value-chain. While there are widespread discussions of a developmental state within the ANC [12], South Africa is still 'failing to change the socio-economic structures that perpetuate racial injustice against black 
people' [11] within the minibus taxi industry. Even after twenty-six years of democracy, the country is still haunted by an informal and unregulated minibus taxi industry. Within the concept of a developmental state, government has an important role to play in enabling the public transport sector to collectively move people daily across the country. What is important here, van Ryneveld notes, is the 'provision of infrastructure, regulation, creation of a sound basis for competition in service provision, contracting of services, subsidies' [20]. For South Africa to become a truly developmental state, 'government needs to strengthen its ability to manage and coordinate diverse interests central to the achievement of South Africa's developmental goals' [21]. In this respect, government should strengthen its ability to coordinate the industry's different interests. The state also needs to regulate working conditions in the industry that remains characterised by the precarious conditions of work.

\section{METHODS}

Using qualitative research methods, the author interviewed 58 participants. The participants were the key informants from the Department of Transport; Gauteng Department of Labour; Gauteng Department of Roads and Transport; Gauteng Provincial Regulatory Entity; SA Taxi Development Finance; South African Transport and Allied Workers Union; South African National Taxi Council; National Taxi Alliance. Most interviews were conducted with taxi owners, taxi drivers and taxi marshals in the four main taxi ranks of the City of Johannesburg. Lastly, interviews were also conducted with the commuters of the minibus taxis. The author performed a thematic analysis of all the interviews conducted.

\section{RESULTS AND DISCUSSION}

\subsection{Further strategic selectivity of the state on public transport}

The South African state privileges formalised public transport strategies over others, because 'institutions are characterised by a pattern of strategic selectivity that reflects and modifies the balance of social forces and, in other word, delineates which interests, strategies, and policies can be enforced in a given context' [10]. In this regard, it appears that government has essentially chosen to attempt to replace the informal taxi industry with various formal modes of transport. Through the Public Transport Transformation's (PTT) programme, the Gauteng Department of Roads and Transport (GDoRT) aims to ensure 'that the taxi industry, Small Business Operations (SBO) and Small, Medium and Micro Enterprises (SMMEs) participate in the provision of subsidised Public Transport Services' [22]. Yet, the industry still does not participate in the provision of subsidised public transport services. This situation is proof of the existence of strategic selectivity as described by Grumiller [10]. Explaining the challenge of not getting subsidies from government, one taxi owner from Bree taxi rank notes:

Our biggest challenge is that we do not get subsidies from government and yet we are the major transporters of commuters in the public transport sector. This condition puts us in difficult positions, especially because taxis are now expensive (Bree Taxi Rank Taxi Owner 1, Interview, 2 August 2018).

From this, it is clear that the state privileges some of the formalised public transport system and strategies over others. This condition results in the precarious existence of the minibus taxi industry. The Passenger Rail Agency of South Africa (PRASA) is one example, 
albeit taking into account the challenges it continues to face. PRASA is a wholly owned government public entity with the responsibility of delivering commuter rail services in the metropolitan areas of South Africa. PRASA continues to face serious systemic and structural challenges due to years of under-investment in passenger rail services. It also faces challenges related to operating costs, which have put the agency in an unviable financial position with decreasing revenue collection. The patronage and customer satisfaction with the agency continues to decline.

The PTT programme focuses on economic transformation through participation in subsidised public transport contracts through sub-contracting and operational cooperation. While the department plans to transform the minibus taxi industry through this programme, it appears that there is a lot to be done to empower the industry through training and development. This situation further places the industry in a condition of precarity. The 2018/2019 Annual Performance Plan (APP) of the GDoRT explains that the sub-programme of the PTT, which is the Corporatisation of Taxi Associations and Portfolio Training, plays the role of empowering the industry. The formalisation of the taxi industry is meant to transform it into a professional and business orientated business. In order to achieve this, the Gauteng Department of Roads and Transport (GDoRT) implemented the Corporatisation Training Programme (Gauteng Department of Roads and Transport 2016). Corporatisation ensures that taxi associations are legal business entities. The GDoRT aims to boost customer service, influence taxi driver actions and assist the taxi industry through skills development as part of an effort to transform the sector. The field research has shown that not all minibus taxi operators are benefiting from the corporatisation of taxi associations. This corporatisation is definitely crucial for transforming the industry, but there should be willingness from industry operators. If successful, the corporatisation process can help transform the industry to the envisioned collaborative minibus taxi industry and eradicate the precariousness of work. This will also help the industry play a meaningful role in the economy of the country.

Through an uninterrupted subsidised bus service in Mamelodi, the department subsidised the Autopax bus services and this contract came to an end as of 30 September 2017. The department entered into a new agreement, in terms of a signed inter-governmental agreement with the City of Tshwane (CoT), in order to ensure the continuity of subsidised bus transport services to Mamelodi commuters. As a result, through this agreement, the City of Johannesburg (CoJ) took over the responsibility of providing public transport in Mamelodi as from 1 October 2017. These bus subsidies were there to ensure that public transport operations fulfilled the needs of commuters. The department makes use of a Bus Subsidy Monitoring system to monitor the performance of subsidised public transport operators. It is clear from this that the state only supports formalised public transport operators. Thus, the minibus taxi industry is excluded from government plans of an integrated public system, with this leading to its continued precarious location. Thus, while post-apartheid South Africa envisioned state intervention (as a principle of a developmental state) in the industry, very little has been done to transform the industry.

\subsection{Minibus taxi industry's continuous challenges}

While the industry spans the formal and informal economies, as explained by the literature [23], due to its informal and unregulated nature, it is characterised by several challenges, which include among others: lack of subsidies; taxi violence; challenges with obtaining operating licenses; and the costs of taxi financing and insurance. The non-existence of 
subsidies in the minibus taxi industry is further explained by the Gauteng MEC for Roads and Transport as follows:

The general accepted principle worldwide is that public transport is subsidised. It is understood that it is subsidised where government largely runs the services. The taxi industry is the privately run service. The question is you have private bus operators that is subsidised and you have private minibus taxes that is not subsidised. The issue now is affordability from government side and what form would the subsidy take and how would you monitor service performance? If a bus operator fails to provide bus services for that day you impose a penalty. You will be able to monitor that because we have monitoring companies, but if you have thousands of minibus taxi operators running unscheduled services, how do you monitor them and how do you give a subsidy? If you change the business model, government can contract a particular company in the particular area to monitor. In this particular area, for this type of commuters you need to provide 50 taxis that will be running according to a schedule. We will pay you a subsidy and we will take you as an operator. Who becomes an operator from government point of view will have to be a competitive process. It's not gonna be a give and take just because you have a taxi. You will have to bid for it. There must be basic service standards. This has to be linked into a model. Is there a willingness on the part of the industry to consider that? I don't see that. That's the point we have made earlier. I don't see a vision from the leadership. I don't see a move to try and consider this. (Former Gauteng MEC for Roads and Transport, Interview, 1 November 2018).

The challenges facing the minibus taxi industry perpetuate the existence of precariousness in the industry in the Global South. Therefore, a precariat is not a single phenomenon produced by globalisation. Precariousness has always been in existence within the minibus taxi industry. Standing writes that 'as globalisation proceeded, and as governments and corporations chased each other in making their labour relations more flexible, the number of people in insecure forms of labour multiplied' [24]. As flexible labour grew, millions of people across the world entered the precariat. Many of those entering the precariat would not know their employers, as Standing argues. The state has not been effective in deliberately intervening in the industry. It increasingly puts the spotlight on formalised public transport, buses and trains, and ignores the informal and unregulated minibus taxi industry. This is an instance of strategic selectivity, to utilise Grumiller's term.

\section{CONCLUSION}

The continued failure of the state to transform the industry signifies a lack of strategic intervention (and strategic selectivity) of the state in the industry. The exclusion of the industry from the Integrated Transport Plans (ITPs) of the municipalities is a case in point. The majority of operators continue to operate illegally, thus making it difficult for departments to regulate. While the industry is currently not subsidised, what is required to implement subsidies within the industry is an accounting system, though this is not possible in the informal industry in which minibus taxis operates. The National Land Transport Transition Act speaks of the need for state subsidies to be directed at assisting marginalised users with respect to lowering the costs of public transport services. Within the industry, there 
is considerable tension between state efforts to regulate labour and resistance on the part of owners (and at times drivers) to inhibit this regulation and formalisation. While noting that government is making plans to transform the industry, a lot still needs to be done. The lack of state strategic intervention in the industry gives rise to the existence of precarity.

\section{ACKNOWLEDGEMENTS}

The author is most grateful to his research participants for granting access and consent to the study. He would like to acknowledge his PhD supervisors, Professor Ashwin Desai and Dr. Siphelo Ngcwangu, for being supportive through the entire research process and for motivating him to write this article. He will forever be grateful to his wife, Anesipho Fobosi, for her consistent support. Thank you to his employer, UNESCO 'Oliver Tambo' Chair of Human Rights at University of Fort Hare for the support in his academic career.

\section{REFERENCES}

[1] Clarke, M.J., 'All the Workers?' Labour Market Reform and Precarious Work in PostApartheid South Africa, 1994-2004 (A dissertation submitted to the faculty of graduate studies in partial fulfilment of the requirements for the Degree of Doctor of Philosophy). York University, Toronto, 2006.

[2] Bourdieu, P., The Social Structures of the Economy, Polity Press: Cambridge, 2005.

[3] Baloyi, M., The impact of the taxi recapitalisation programme on the South African taxi industry: A case study of greater Mankweng taxi association in Capricorn district, Limpopo province. Master's thesis, Master of Administration (Public Administration), University of Limpopo, Limpopo, 2012.

[4] Chiloane-Tsoka, G.E., Factors affecting the implementation of the taxi recapitalization project: The department of transport. Problems and Perspectives in Management, 14(4), pp. 25-32, 2005.

[5] Hua, J. \& Ray, K., Beyond the precariat: Race, gender, and labour in the taxi and uber economy. Social Identities, 24(2), pp. 271-289, 2017.

[6] Moyake, M.S., A critical analysis of the process of taxi recapitalisation policy (Master's thesis in Development and Management in the Department of Public Management and Administration). North-West University, North West, 2006.

[7] Ntuli, S., Investigating the impact of the TRP on the transport industry: A case study of the Warwick avenue taxi rank in the Ethekwini Municipality (Master's thesis in Public Policy). University of Kwazulu-Natal, KZN, 2015.

[8] Woolf, S.E., South African taxi hand signs documenting the history and significance of taxi hand signs through anthropology and art, including the invention of a tactile shape-language for blind people (A thesis submitted to The Faculty of Humanities, University of the Witwatersrand, Johannesburg, in fulfilment of the requirements for the degree of Doctor of Philosophy). University of Witwatersrand, Johannesburg, 2013.

[9] Jessop, B., The Capitalist State, New York University Press: New York, 1982.

[10] Grumiller, J.A., Strategic-relational approach to analyzing industrial policy regimes within global production networks: The Ethiopian leather and leather products sector, 2019. https://www.econstor.eu/handle/10419/205135. Accessed on: 29 Mar. 2021.

[11] Tshishonga, N. \& de Vries, M., The potential of South Africa as a developmental state a political economy critique. African Journal of Public Affairs, 4(1), pp. 58-69, 2011. 
[12] Burger, P., How suitable is a 'developmental state' to tackle unemployment, inequality and poverty in South Africa? 2014. https://www.econ3x3.org/article/how-suitable$\% \mathrm{E} 2 \% 80 \% 98$ developmental-state $\% \mathrm{E} 2 \% 80 \% 99$-tackle-unemployment-inequalityand-poverty-south-africa. Accessed on: 29 Mar. 2021.

[13] Freund, B., Twentieth-Century South Africa: A Developmental History, Cambridge University Press: Cambridge, 2019.

[14] Mathebula, N.E., An impossible developmental state in the South African context: A true reflection of the Asian tigers? Bangladesh e-Journal of Sociology, 13(1), pp. 4655, 2016.

[15] Edigheji, O., Constructing a Democratic Developmental State in South Africa: Potentials and Challenges, HSRC Press: Cape Town, South Africa, 2010.

[16] Soon-Yang, K., The east Asian developmental state and its economic and social policies: The case of Korea. International Review of Public Administration, 12(2), pp. 69-87, 2014.

[17] Mkandawire, T., Thinking about developmental states in Africa. Cambridge Journal of Economics, 25(3), pp. 289-313, 2001.

[18] Marais, H., South Africa Pushed to the Limit: The Political Economy of Change, Zed Books: London, New York, 2011.

[19] Evans, P., Embedded Autonomy: States and Industrial Transformation, Princeton University Press: United Kingdom, 1995.

[20] van Ryneveld, P., Urban transport analysis for the urbanisation review, 2018. https://csp.treasury.gov.za/Resource\%20_Centre/Conferences/Documents/ Urbanization\%20Review\%20Papers/Paper\%209\%20-\%20Urban\%20Transport\% 20Analysis.pdf. Accessed on: 29 Mar. 2021.

[21] De Wee, K., 'Is South Africa ready to be a developmental state?' Africa's Public Service Delivery and Performance Review, 4(3), pp. 488-502, 2016.

[22] Gauteng Department of Roads and Transport, 2017/18 Annual Report (Annual Report 2017/18), Gauteng Department of Roads and Transport: Johannesburg. https://www.gov.za/sites/default/files/gcis_document/201911/dotannualreport201819 .pdf. Accessed on: 29 Mar. 2021.

[23] Barrett, J., Organizing in the Informal Economy: A Case Study of the Minibus Taxi Industry in South Africa, 2003, International Labour Organisation. https://www.ilo.org/wcmsp5/groups/public/---ed_emp/---emp_ent/---ifp_seed/ documents/publication/wcms 117698.pdf. Accessed on: 29 Mar. 2021.

[24] Standing, G., The Precariat: The New Dangerous Class, Bloomsbuy Academic, 2011. 